\title{
Microbial soil quality indicators under different crop rotations and tillage management ${ }^{1}$
}

\author{
Indicadores microbianos da qualidade do solo sob diferentes rotações de culturas e \\ manejo do solo
}

\author{
Enderson Petrônio de Brito Ferreira ${ }^{2 *}$, Henrique Pereira dos Santos ${ }^{3}$, Janaina Ribeiro Costa ${ }^{4}$ Helvécio De-Polli $^{5}$ \\ e Norma Gouvêa Rumjanek ${ }^{4}$
}

\begin{abstract}
An experiment was carried out under field conditions to assess the effects of soil management (no-tillage- NT and conventional tillage- $\mathrm{CT}$ ) and crop rotation systems on microbial biomass- $\mathrm{C}\left(\mathrm{C}_{\text {mic }}\right)$, basal soil respiration (BSR), metabolic quotient $\left(\mathrm{qCO}_{2}\right)$, soil organic carbon content $\left(\mathrm{C}_{\text {org }}\right)$ and microbial carbon to organic carbon ratio $\left(\mathrm{C}_{\text {mic }} / \mathrm{C}_{\text {org }}\right)$. Soil samples were collected on an area cultivated with wheat as winter crop and soybean as summer crop, both in rotation with vetch, maize and oats. Samples were also collected in a secondary forest used as reference. Data of each management system (NT and CT) were compared to forest area by " $\mathrm{t}$ " test $(\mathrm{p}<0.05)$ and crop rotations were compared by Tukey test $(\mathrm{p}<0.05)$. All data were submitted to multivariate analysis (Principal Component Analysis - PCA). There were observed significant differences (" $t$ " test; $p<0.05$ ) for $\mathrm{C}_{\text {mic }}, \mathrm{BSR}, \mathrm{qCO}_{2}$ and $\mathrm{C}_{\text {mic }} / \mathrm{C}_{\text {org }}$ between $\mathrm{NT}$ and $\mathrm{CT}$, by which NT values resemble those for forest area. For crop rotations significant differences (Tukey test; $\mathrm{p}<0.05$ ) were found only for $\mathrm{BSR}$ and $\mathrm{qCO}_{2}$. The sum of the two first principal components on the PCA explained about $75 \%$ of the data variation. PCA showed NT closest to forest area than CT, especially treatments with soybean and vetch as consecutive crops. The forest area-NT clustering was mostly due to $\mathrm{C}_{\text {mic }}$ and $\mathrm{C}_{\text {mic }} / \mathrm{C}_{\text {org }}$ relationship. Results indicate that the NT system is more sustainable than the CT system and can contribute for the accumulation a greater quantity of carbon in soil.
\end{abstract}

Key words - Microbial biomass. Microbial respiration. Organic matter. Soil management.

Resumo - Foi conduzido um experimento sob condições de campo para avaliar o efeito da forma de manejo do solo (Plantio direto - PD e plantio convencional - PC) e dos sistemas de rotação de culturas sobre o carbono da biomassa microbiana $\left(\mathrm{C}_{\text {mic }}\right)$, respiração basal do solo (RBS), quociente metabólico $\left(\mathrm{qCO}_{2}\right)$, carbono orgânico total $\left(\mathrm{C}_{\mathrm{org}}\right)$ e relação carbono da biomassa microbiana: carbono orgânico total $\left(\mathrm{C}_{\text {mic }} / \mathrm{C}_{\text {org }}\right)$. As amostras de solo foram coletadas em uma área cultivada com trigo como cultura de inverno e soja como cultura de verão, ambas em rotação com ervilhaca, milho e aveia preta. Amostras de solo também foram coletadas em uma floresta secundária usada com referência. Os dados de cada sistema de manejo do solo (PD e PC) foram comparados com a floresta secundária pelo teste " $t$ " $(p<0.05)$ e as rotações de culturas foram comparadas pelo teste de Tukey $(\mathrm{p}<0.05)$. Todos os dados foram submetidos a uma análise multivariada (Análise de Componentes Principais - ACP). Foram observadas diferenças significativas (teste " $\mathrm{t}$ "; $\mathrm{p}<0.05$ ) para $\mathrm{C}_{\text {mic }}, \mathrm{RBS}, \mathrm{qCO}_{2}$ e $\mathrm{C}_{\text {mic }} / \mathrm{C}_{\text {org }}$ entre PD e PC, em que estes valores foram semelhantes àqueles encontrados na floresta. Entre as rotações de culturas foram observadas diferenças significativas (teste de Tukey; $\mathrm{p}<0.05$ ) apenas para $\mathrm{RBS}$ e $\mathrm{qCO}_{2}$. A análise de componentes principais mostrou que o PD aproximou-se mais da floresta do que o PC, especialmente nos tratamentos em que soja e ervilhaca faziam parte da rotação de culturas antes do trigo. A formação do agrupamento entre floresta e $\mathrm{PD}$ ocorreu principalmente devido ao $\mathrm{C}_{\text {mic }}$ e à relação $\mathrm{C}_{\text {mic }} / \mathrm{C}_{\text {org }}$. Os resultados indicam que o PD apresenta maior sustentabilidade que o PC, podendo contribuir para o acúmulo de uma grande quantidade de carbono no solo.

Palavras-chave - Biomassa microbiana. Respiração microbiana. Matéria orgânica. Manejo do solo.

\footnotetext{
* Corresponding author

${ }^{1}$ Received 30/07/2009; accepted 14/04/2010

Pesquisa financiada pela CAPES e Embrapa Trigo

${ }^{2}$ Pesquisador da Embrapa Arroz e Feijão, Rodovia GO-462, km 12, Caixa Postal 179, Santo Antônio de Goiás-GO, Brasil, 74375-000, enderson@ cnpaf.embrapa.br

${ }_{3}^{3}$ Pesquisador da Embrapa Trigo, Rodovia BR 285, km 294, Passo Fundo-RS, Brasil, 99001-970, hpsantos@cnpt.embrapa.br ${ }^{4}$ Pesquisadora da Embrapa Agrobiologia, Rodovia BR 465, km 7, Seropédica-RJ, Brasil, 23890-000, janaina@cnpab.embrapa.br, norma@cnpab. embrapa.br

${ }^{5}$ Pesquisador da Embrapa Agrobiologia, Rodovia BR 465, km 7, Seropédica-RJ, Brasil, 23890-000, depolli@cnpab.embrapa.br
} 


\section{Introduction}

The use of conventional system combined with excessive use of fertilizers and pesticides leads to loss in health and soil quality. Besides, depletion of soil organic carbon and associated nutrients in soil organic matter and intensive tillage causes severe negative impacts to the environment, by subjecting bare soil to erosive processes. Soil degradation and contamination of underground water, may also occur from residues of pesticides and fertilizers widely employed under this agricultural model. Oldeman (1994) has pointed out that this model of soil exploitation results in environmental degradation that goes far beyond its simple ecological aspects, which leads to irreversible environmental damage with destruction of fauna and flora and loss of agricultural soil (LEONARDOS et al., 2000), and greenhouse gases emission (ELDER; LAL, 2008).

According to Batjes (1998), the global average of $\mathrm{C}$ liberation to the atmosphere in the 1980 s was $7.1 \pm 1.1$ Gt C year ${ }^{-1}$, from which, 1.6 $\pm 1.0 \mathrm{Gt} \mathrm{C}$ year $^{-1}$ was due to agriculture in tropical regions and $5.5 \pm 0.5 \mathrm{Gt}$ year $^{-1}$ due to the burning of fossil fuels. Similar amounts were described for the 1990s where the total emission was estimated to be $7.0 \mathrm{Gt}$ year ${ }^{-1}$ of C, from which, $5.5 \mathrm{Gt}_{\text {year }}{ }^{-1}$ was due to fossil fuel burning and $1.2 \mathrm{Gt}$ year $^{-1}$ was due to agricultural soil use and deforestation (International..., 1996 cited by RESCK, 2001).

Joint scientific efforts have been focused on the development of systems capable of maintaining high yields while promoting greater sustainability to the agroecosystem through the use of alternative soil management practices, improved varieties and crop rotations. However, irrespectively of the adopted system, soil management will always result in changes in some soil characteristics. These variations have an important effect on the soil microbial community (GUNDALE et al., 2005) which in turn affects agroecosystem function and consequently crop yield.

Besides the influence of soil management on total microbial biomass, it also affects differentially the biomass activity resulting in greater or smaller $\mathrm{CO}_{2}$ efflux. Nowadays the trend is towards soil management practices capable of increasing the immobilization of atmospheric $\mathrm{CO}_{2}$. According to Hermle et al. (2008), it may be possible to manipulate paddy soil through conservational tillage and crop practices, and thereby maintain adequate soil organic matter concentrations, and mitigate soil organic carbon loss from soil to atmosphere, which increases $\mathrm{C}$ content and microbial activity (FRANCHINI et al., 2007; MOSCATELLI et al., 2005; ROLDÁN et al., 2005).

Soil microbial communities are influenced by many factors as soil management and cover crops (CARRERA et al., 2007); kind of fertilizer and its applying way (CARRERA et al., 2007); plant development stage and cultivars (FERREIRA et al., 2008) as well as pesticides (FERREIRA et al., 2009). Thus, microbial properties allied to the total organic $\mathrm{C}$ content can be used to evaluate the sustainability of agricultural production. These properties are described as biological indicators capable of detecting changes in soil quality and its biological properties (NOGUEIRA et al., 2006). High contents of organic C on the soil surface is an important factor contributing to the $\mathrm{C}_{\text {mic }}$ content in soil (VARGAS; SCHOLLES, 2000) which has been reported as a key factor for microbial community growth (MOSCATELLI et al., 2005).

This work aimed to determine the effects of soil management and crop rotation systems on soil microbial biomass and organic carbon and to verify the use of these parameters as indicators of soil quality.

\section{Material and methods}

This study was carried out in a long-term experiment conducted since 1996 at the Experimental Station at the National Wheat Research Center (Embrapa) in Passo Fundo, Rio Grande do Sul State, Brazil (28 $12^{\prime} 56^{\prime \prime} \mathrm{S}$ and $52^{\circ} 23^{\prime} 43^{\prime \prime} \mathrm{W}$, altitude $\left.684 \mathrm{~m}\right)$. The soil at the site is an Haplic ferralsol $\left(10 \mathrm{~g} \mathrm{~kg}^{-1}\right.$ of soil of coarse sand; $230 \mathrm{~g} \mathrm{~kg}^{-1}$ of soil of fine sand; $130 \mathrm{~g} \mathrm{~kg}^{-1}$ of soil of silt; $630 \mathrm{~g} \mathrm{~kg}^{-1}$ of soil of clay).

Crop rotations were evaluated in 2 management systems: no-tillage (NT) and conventional tillage (CT) where a disc plough was used. Crop rotations consisted of wheat (Triticum aestivum L.) and soybean (Glycine max (L.) Merrill) as the main crops for winter and summer, respectively, and vetch (Vicia sativa L.), maize (Zea mays L.) and oats (Avena sativa L.) as secondary crops for the rotation system. Three different rotation were used: 1- wheat/soybean (W/S); 2- wheat/soybean/vetch/maize (W/S/V/M); 3- wheat/soybean/vetch/maize/oats/soybean $(\mathrm{W} / \mathrm{S} / \mathrm{V} / \mathrm{M} / \mathrm{O} / \mathrm{S})$, in a way that all possible combinations had been cultivated at the same cropping season, resulting in 6 subplots per management system for each replicate. The experiment was carried out in a split-plot randomized block design with 3 replicates. The management systems (NT and CT) were the main plots and the subplots were the crop rotation treatments.

Composite samples consisting of 6 sub-samples per plot were taken at $0-10 \mathrm{~cm}$ depth. Soil sampling was also carried out in a neighboring secondary forest area (Araucaria woodland).

Microbial biomass- $\mathrm{C} \quad\left(\mathrm{C}_{\text {mic }}\right)$ and basal soil respiration (BSR) were performed by the use of three $20 \mathrm{~g}$ 
sub-samples derived from composite soil samples at $60 \%$ of field capacity. They were then homogenized and sieved through a $2 \mathrm{~mm}$ sieve. Microbial biomass- $\mathrm{C}\left(\mathrm{C}_{\text {mic }}\right)$ evaluation was carried out by fumigation-extraction method (VANCE et al., 1987) using soil:extract solution ratio of 1:2.5 and a correction factor (kc) of 0.33 (TATE et al,. 1988). For the fumigation step $1 \mathrm{~mL}$ of ethanol-free chloroform was added to each sub-sample flask of $100 \mathrm{~mL}$, kept tight closed, and after incubation of 24 hour the chloroform was allowed to evaporate in the fume hood for $60 \mathrm{~min}$. After that, the extraction and titration were performed according to Vance et al. (1987). Basal soil respiration (BSR) was determined according to Jenkinson and Powlson (1976) where three $20 \mathrm{~g}$ sub-samples of soil were placed in a $3 \mathrm{~L}$ flask and incubated for 5 days at $28^{\circ} \mathrm{C}$. $\mathrm{CO}_{2}$ was trapped in a $100 \mathrm{~mL}$ flask containing $10 \mathrm{~mL}$ of $\mathrm{NaOH}(1 \mathrm{M})$. After this period, $2 \mathrm{~mL}$ of $\mathrm{BaCl}_{2}(10 \%)$ was used to precipitate the $\mathrm{CO}_{2}$ and the excess $\mathrm{NaOH}$ was titrated using $\mathrm{HCl}(0.5 \mathrm{M})$.

The specific microbial respiration, or metabolic quotient $\left(\mathrm{qCO}_{2}\right)$, expresses the C-CO evolved per unit of microbial biomass and time. Metabolic quotient was calculated according to the procedures described by Anderson and Domsch (1990) and expressed as $\mathrm{mg} \mathrm{C} \mathrm{g} \mathrm{C}_{\text {mic }}{ }^{-1} \mathrm{~h}^{-1}$.

Organic carbon content $\left(\% \mathrm{C}_{\text {org }}\right)$ was determined by potassium dichromate oxidation. The ratio of microbial biomass- $\mathrm{C}$ to organic carbon $\left(\mathrm{C}_{\text {mic }} / \mathrm{C}_{\text {org }}\right)$ was calculated according to Jenkinson and Ladd (1981).

Data were submitted to analysis of variance and significant differences were determined by Tukey's test at $\mathrm{p}<0.05$. To compare data from NT, CT and the forest area, a ' $t$ ' test was used at $\mathrm{p}<0.05$ and values found for forest area were used as a reference. Previously to variance analysis, data were submitted to Lilliefors and CoChran-Bartlett tests to verify its normality and homogeneity of variances using the software SAEG v. 7 (EUCLYDES, 1982). Comparisons between forest area and both NT and CT treatments should be done with care as the forest area was not part of the experimental design. A principal component analysis (PCA) was performed using the software CANOCO v. 4.5 (ter BRAAK; SMILAUER, 2002), for data obtained for all the parameters studied involving a matrix of 13 lines by 5 columns, representing treatments and parameters, respectively. The determination of the number of principal components used for the treatments clustering was defined according to Jollife (2002), since the sum of the first 2 principal components (PC1 and PC2) was greater than 70\%.

\section{Results and discussion}

Table 1 shows $\mathrm{C}_{\text {mic }}, \mathrm{BSR}, \mathrm{qCO}_{2}, \mathrm{C}_{\text {org }}$ and $\mathrm{C}_{\text {mic }} / \mathrm{C}_{\text {org }}$ values obtained for NT, CT and forest area. Mean test between NT and CT was performed by Tukey's test, and forest area was compared separately with each management systems (NT and CT) by " $t$ " test. Significant differences between NT and CT were observed to $\mathrm{C}_{\text {mic }}, \mathrm{BSR}, \mathrm{qCO}_{2}$ and $\mathrm{C}_{\text {mic }} / \mathrm{C}_{\text {org }}$. Values of $\mathrm{C}_{\text {mic }}$ and $\mathrm{C}_{\text {org }}$ of forest area were greater than NT and CT, and the $\mathrm{C}_{\text {mic }} / \mathrm{C}_{\text {org }}$ of forest area was greater than CT but not statistically different of NT (Table 1). Fialho et al. (2006) did not found significant difference for $\mathrm{C}_{\text {mic }}$ between cultivated and forest area, however forest area showed a tendency to present greater values of $\mathrm{C}_{\text {mic }}$ than cultivated area.

$\mathrm{C}_{\text {mic }}$ value for NT was greater than $\mathrm{CT}$ and closer to forest area, suggesting that this system could promote a greater sustainability level compared to CT. Furthermore NT increases the litter accumulation rate on the soil surface which improves both the $\mathrm{C}$ content and microbial activity (MOSCATELLI et al., 2005; ROLDÁN et al., $2005)$, indicating a close association between these results and the low impacts to the environment caused by the NT system (HERMLE et al., 2008).

BSR did not show significant difference among soil management systems (NT and CT) and forest area, however NT was statistically different of CT (Table 1). The greatest values of BSR were expected in the treatments with the greatest $\mathrm{C}_{\text {mic }}$ values, such as NT and forest area, that compared to $\mathrm{CT}$ promoted greater $\mathrm{CO}_{2}$ efflux. According to Zornoza et al. (2007), BSR shows a close relation to abiotic soil conditions such as temperature and humidity. Besides, the greatest quantity of organic material in the forest area

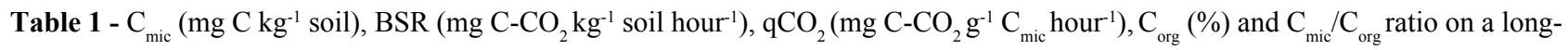
term experiment under NT, CT and forest area within $0-10 \mathrm{~cm}$ depth

\begin{tabular}{cclccc}
\hline Treatments & Cmic & BSR & qCO2 & Corg & Cmic/Cor \\
\hline CT & $97.22 \mathrm{~b}^{*}$ & $0.10 \mathrm{~b}$ & $1.07 \mathrm{a}$ & $1.21 \mathrm{a}^{*}$ & $0.86 \mathrm{~b}^{*}$ \\
$\mathrm{NT}$ & $153.39 \mathrm{a}^{*}$ & $0.15 \mathrm{a}$ & $0.99 \mathrm{~b}$ & $1.15 \mathrm{a}^{*}$ & $1.34 \mathrm{a}$ \\
\hline Forest area & 263.79 & 0.23 & 0.99 & 1.40 & 1.92 \\
\hline
\end{tabular}

Same letters means no significant differences among treatments in the same column (Tukey's test $p<0.05$ ) and asterisk means significant difference between each treatment and forest area ("t" test $p<0.05$ ) 
and NT reflects upon the decomposing microbial activity and, consequently on the BSR growth, as stated by Vargas and Scholles (2000) that found a correlation between the soil warming and substrate availability with BSR.

Significant differences in $\mathrm{qCO}_{2}$ values were observed to NT system when compared to CT. However, both treatments were not different to forest area (Table 1). Compared to CT, NT showed lowest $\mathrm{qCO}_{2}$ value and, consequently, greater sustainability because the soil microbial population under NT was less stressed, indicating the lowest relative loss of $\mathrm{CO}_{2}$, which, in the long-term can translate into a greater accumulation of $\mathrm{C}$ in the soil (FRANCHINI et al., 2007). Besides, a low $\mathrm{qCO}_{2}$ indicates a high quality of the substrate used by microorganisms or a low microbial maintenance requirement (SARMIENTO; BOTTNER, 2002). In addition, even with the lowest content of $\mathrm{C}_{\text {mic }}$, CT can promote greater $\mathrm{qCO}_{2}$ values due to differences in the substrate accessibility by the microorganisms, metabolic patterns changing or by the alteration of the soil microbial composition (ALVAREZ et al., 1995). According to Dilly et al. (2001), lowest values of $\mathrm{qCO}_{2}$ are normally found under forest vegetation compared with cultivated areas because forest systems show greater stability and, therefore lower disturbance on the soil microbial community.

$\mathrm{C}_{\text {org }}$ content under NT and CT showed a significant difference compared with the forest area, however, under the present study conditions it was not possible to verify significant difference in $\mathrm{C}_{\text {org }}$ content between NT and CT management practices (Table 1). This result may be possible because $\mathrm{C}_{\text {org }}$ assessment was only performed on the soil surface $\left(0-10 \mathrm{~cm}\right.$ depth), and differences on $\mathrm{C}_{\text {org }}$ contents may occur on the whole soil profile, as stated by Sisti et al. (2004) that found significant differences for C stocks through the soil profile under crop rotations in this same experimental area.

Data for $\mathrm{C}_{\text {mic }} / \mathrm{C}_{\text {org }}$ ratio show that there were significant differences only for CT, when the tillage treatments were compared to the forest area. In addition, between management systems the lowest value was found under CT management, indicating that the quantity of $\mathrm{C}_{\text {mic }}$ as a proportion of the total soil $\mathrm{C}_{\text {org }}$ is greater under the forest area and NT than under CT.

As reported by Jenkinson and Ladd (1981), the $\mathrm{C}_{\text {mic }} / \mathrm{C}_{\text {org }}$ ratio is related to the changes in the quantities of soil C. In both the forest area and NT the greatest values of $\mathrm{C}_{\text {mic }} / \mathrm{C}_{\text {org }}$ ratio suggest that a greater quantity of biomass is supported per organic carbon unit derived from the inputs of $\mathrm{C}$ in the system.

Data on Table 1 indicate a more evident impact of the CT on the soil quality indicators, which may be resulted as a consequence of the degradation of the natural soil conditions (OLDEMAN, 1994) and/or by a strong impact on the fauna and flora and loss of agricultural soil (LEONARDOS et al., 2000).

Table 2 shows the effects of crop rotations within each management system. Significant differences were found only for BSR and $\mathrm{qCO}_{2}$ within each crop rotation (Table 2). Under NT BSR was higher for crop rotation $\mathrm{IIb}$, while the highest value for CT was observed in the crop rotation IIIc. In both rotations soybean was included as the summer crop but during the sampling period, vetch, a leguminous plant, was under cultivation. On the other hand, the lowest values of BSR were found in the crop rotations IIIb and I for NT and CT, respectively, when wheat was under cultivation. These data suggests that a succession of legume plants (soybean and vetch), as presented for NT and CT, in the crop rotations IIb and IIIc, respectively, may increase microbial activity represented by the $\mathrm{CO}_{2}-\mathrm{C}$ evolved.

Some factors such as $\mathrm{C} / \mathrm{N}$ ratio (RAUT et al., 2008) and $\mathrm{N}$ content (WANG et al., 2008) have a great influence on the decomposition and mineralization of the organic matter. Compared with wheat, the organic residues of vetch had a smaller $\mathrm{C} / \mathrm{N}$ ratio and a greater $\mathrm{N}$ content, which contributed to the faster decomposition of its residues results in a greater $\mathrm{CO}_{2}$ efflux rate.

The metabolic quotient $\left(\mathrm{qCO}_{2}\right)$ was lower for the crop rotation IIIb under NT, and for the crop rotation I under CT (Table 2). In both crop rotations soybean was followed by wheat, which possibly had been influenced the low values of BSR observed under these crop rotations. Greater values of $\mathrm{qCO}_{2}$ were found in the crop rotations IIb and IIIa under NT and IIIc under CT (Table 2). Except for crop rotation IIIa under NT, the other crop rotations had soybean/vetch in succession, and as stated above this situation may had influenced the high values of BSR under these treatments, resulting on high values of $\mathrm{qCO}_{2}$.

Compared to data displayed on tables of mean tests, principal component analysis (PCA), provides more details of the interactions between the studied variables once it mitigate the data variation into several components and allows a multidimensional view of the data, which complements the information of the mean tests, helping the interpretation of the data. The difference between the $\mathrm{X}$ and $\mathrm{Y}$ axes with our data was about $20 \%$, indicating that $\mathrm{X}$ axis was the most important for data interpretation because it had been explained most of the data variation.

The PCA was performed with basis on the data of $\mathrm{C}_{\text {mic }}, \mathrm{BSR}, \mathrm{qCO}_{2}, \mathrm{C}_{\text {org }}$ and $\mathrm{C}_{\text {mic }} / \mathrm{C}_{\text {org }}$. The first three principal components discriminated $94.9 \%$ of all information. However, the sum of the first two principal components 
Table $2-\mathrm{C}_{\text {mic }}\left(\mathrm{mg} \mathrm{C} \mathrm{kg}^{-1}\right.$ soil), BSR (mg C- $\mathrm{CO}_{2} \mathrm{~kg}^{-1}$ soil hour $\left.{ }^{-1}\right), \mathrm{qCO}_{2}\left(\mathrm{mg} \mathrm{C}_{-} \mathrm{CO}_{2} \mathrm{~g}^{-1} \mathrm{C}_{\text {mic }}\right.$ hour-1 $), \mathrm{C}_{\text {org }}(\%)$ and $\mathrm{C}_{\text {mic }} / \mathrm{C}_{\text {org }}$ ratio on a longterm experiment under NT and CT management for the $0-10 \mathrm{~cm}$ depth interval

\begin{tabular}{ccccccc}
\hline Soil tillage & Crop rotation* & $\mathrm{C}_{\text {mic }}$ & $\mathrm{BSR}$ & ${ }_{\mathrm{a}} \mathrm{CO}_{2}$ & $\mathrm{C}_{\text {org }}$ & $\mathrm{C}_{\text {mic }} / \mathrm{C}_{\text {org }}$ \\
\hline \multirow{3}{*}{ No-Tillage } & I & 146.13 & $0.14 \mathrm{bc}$ & $0.96 \mathrm{ab}$ & 1.15 & 1.26 \\
& IIa & 144.22 & $0.15 \mathrm{~b}$ & $1.04 \mathrm{ab}$ & 1.14 & 1.28 \\
& IIb & 181.73 & $0.22 \mathrm{a}$ & $1.21 \mathrm{a}$ & 1.16 & 1.59 \\
& IIIa & 108.24 & $0.13 \mathrm{bc}$ & $1.20 \mathrm{a}$ & 1.22 & 0.89 \\
& IIIb & 168.26 & $0.08 \mathrm{c}$ & $0.48 \mathrm{~b}$ & 1.15 & 1.45 \\
& IIIc & 171.73 & $0.18 \mathrm{ab}$ & $1.05 \mathrm{ab}$ & 1.09 & 1.57 \\
\hline \multirow{3}{*}{ Conventional Tillage } & I & 106.77 & $0.06 \mathrm{~d}$ & $0.56 \mathrm{~b}$ & 1.14 & 0.93 \\
& IIa & 118.44 & $0.12 \mathrm{bc}$ & $1.01 \mathrm{ab}$ & 1.20 & 0.99 \\
& IIb & 72.22 & $0.07 \mathrm{~cd}$ & $0.97 \mathrm{ab}$ & 1.32 & 0.83 \\
& IIIa & 103.83 & $0.08 \mathrm{~cd}$ & $0.77 \mathrm{ab}$ & 1.24 & 0.84 \\
& IIIb & 92.82 & $0.07 \mathrm{~cd}$ & $0.75 \mathrm{ab}$ & 1.20 & 0.78 \\
\hline Coefficient of variation (\%) & 89.24 & $0.21 \mathrm{a}$ & $2.35 \mathrm{a}$ & 1.17 & 0.76 \\
\hline
\end{tabular}

* I- wheat/soybean; IIa- wheat/soybean/vetch/maize, with wheat as the winter cropping; IIb- wheat/soybean/vetch/maize, with vetch as the winter cropping; IIIa- wheat/soybean/vetch/maize/oats/soybean, with oats as the winter cropping; IIIb- wheat/soybean/vetch/maize/oats/soybean, with wheat as the winter cropping; IIIc- wheat/soybean/vetch/maize/oats/soybean, with vetch as the winter cropping. Same or none letters means no significant differences among treatments in the same column within management system (Tukey's $p<0.05$ )

explained $79.2 \%$ of the information, with a contribution of $43.1 \%$ on PC1 and $36.1 \%$ on PC2. The most important parameters for the distribution of the treatments along $\mathrm{X}$ axis (PC1) were $\mathrm{C}_{\text {mic }}$ and the $\mathrm{C}_{\text {mic }} / \mathrm{C}_{\text {org }}$ ratio and $\mathrm{qCO}_{2}$, while $\mathrm{BSR}$ had a greater influence for the distribution along the $\mathrm{Y}$ axis (PC2) (Figure 1), which are key characteristics of the multivariate approach of principal component analysis (PCA) on distinguishing areas as a function of the soil management (SENA et al., 2002).

Data from PCA showed a clear separation between CT and NT, in which NT treatments had clustering closer to the forest area than CT, except for NT-IIIa (Figure 1).

PC1 shows that treatments under NT are closer to the forest area and they are more dispersed than CT treatments (Figure 1). NT is closer to the forest area because under this management system a high quantity of $\mathrm{C}_{\text {mic }}$ and $\mathrm{C}_{\text {mic }}$ / $\mathrm{C}_{\text {org }}$ were accumulated than under CT (Table 1). Treatments NT-IIb and NT-IIIc both had consecutive crop rotations with the same legume plants in the last 2 cropping seasons (soybean/vetch - Table 2), and high values of $\mathrm{C}_{\text {mic }}$ and $\mathrm{C}_{\text {mic }}$ / $\mathrm{C}_{\mathrm{org}}$. High concentrations of organic $\mathrm{C}$ in soil promote greater $\mathrm{C}_{\text {mic }}$ accumulation (ALVAREZ et al., 1995; VARGAS; SCHOLLES, 2000) which can be used by soil microorganisms for their growth (MOSCATELLI et al., 2005), reflecting the greater concentration of $\mathrm{C}_{\text {mic }}$ in the soil. This fact could explain the position of both treatments NT-IIb, NT-IIIb and NT-IIIc closest to the forest area (Figure 1).
Treatments distributed along PC2, represented by the $\mathrm{Y}$ axis, were most influenced by BSRs. Along this axis, treatments SFA and NT-IIb had showed the greatest

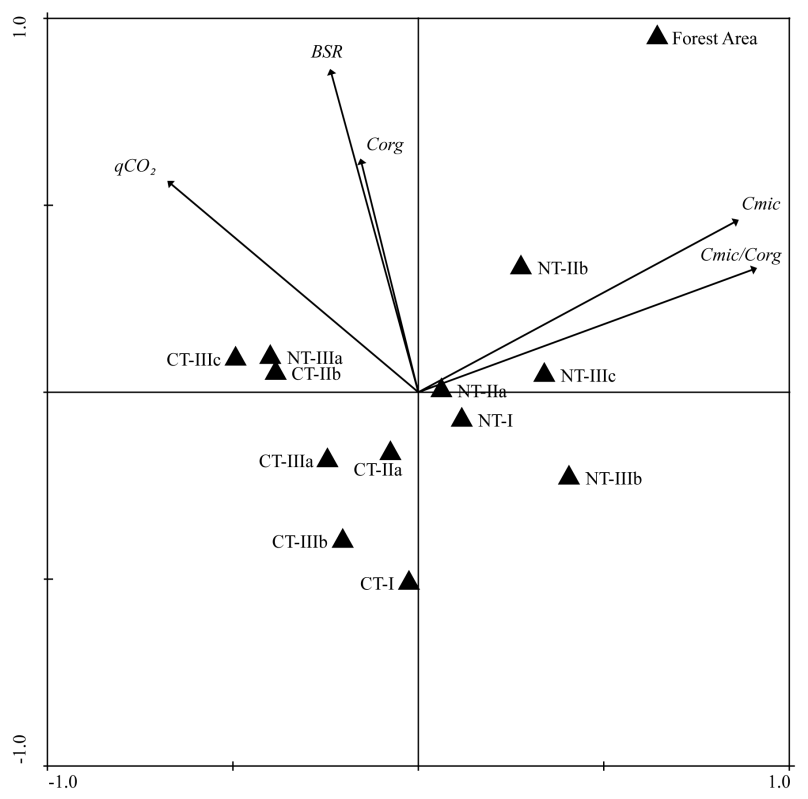

Figure 1 - PCA of the influence of each variety $\left(\mathrm{C}_{\text {mic }}, \mathrm{BSR}, \mathrm{qCO}_{2}\right.$, $\mathrm{C}_{\text {org }}$ and $\mathrm{C}_{\text {mic }} / \mathrm{C}_{\text {org }}$ ) on the distribution of soil management systems (NT: no-tillage; CT: conventional tillage) and crop rotations I, IIa, IIb, IIIa, IIIb and IIIc (Table 2) 
distance from the CT-I and CT-IIIb (Figure 1), in which the first two treatments showed high values of BRS, while low values were found for CT-I and CT-IIIb treatments. Therefore, crop rotation system could have stimulated microbial activity, resulting in greater BSR without an increase in the $\mathrm{C}_{\text {mic }}$ content.

Within NT treatments, the rotation NT-IIIa was very distinct from the others (Figure 1). Among NT treatments, this rotation presumably shows the greatest $\mathrm{C}$ : $\mathrm{N}$ ratio because this system had consecutive crop rotations with cereals in the last 2 cropping seasons (maize/oats Table 2). Possibly such conditions influenced soil organic matter decomposition, reflecting the greater rates of BSR during the studied period.

The ratio of microbial biomass- $\mathrm{C}$ to organic carbon $\left(\mathrm{C}_{\text {mic }} / \mathrm{C}_{\text {org }}\right)$, and the metabolic quotient $\left(\mathrm{qCO}_{2}\right)$ associated with soil microbial activity, have been used by many authors as indices to determine the sustainability of agricultural systems. According to Araújo et al. (2008), the ratio $\mathrm{C}_{\text {mic }} / \mathrm{C}_{\text {org }}$ was significantly enhanced by organic management, improving soil microbial characteristics and slowly increasing soil organic C. Moscatelli et al. (2007) verified that soil management alters the values of $\mathrm{qCO}_{2}$. Franchini et al. (2007) reported that the decrease in $\mathrm{qCO}_{2}$ under NT allowed enhancements in soil C stocks, such that in the $0-40 \mathrm{~cm}$ profile, a gain of $2500 \mathrm{~kg}$ of $\mathrm{C} \mathrm{ha}^{-1}$ was observed in relation to $\mathrm{CT}$, evidence of a smaller relative loss of $\mathrm{CO}_{2}$ and, consequently a larger accumulation of $\mathrm{C}$.

\section{Conclusions}

1. Microbial carbon $\left(\mathrm{C}_{\text {mic }}\right)$, basal soil respiration (BSR), metabolic quotient $\left(\mathrm{qCO}_{2}\right)$ and microbial carbon/ organic carbon ratio $\left(\mathrm{C}_{\text {mic }} / \mathrm{C}_{\text {org }}\right)$ are efficient to determine differences between NT and CT management but only BSR and $\mathrm{qCO}_{2}$ are suitable to identify significant differences among crop rotations systems.

2. $\mathrm{C}_{\text {mic }}, \mathrm{C}_{\text {org }}$ and $\mathrm{C}_{\text {mic }} / \mathrm{C}_{\text {org }}$ are key indicators on determining the soil quality, which is clearly observed by the close clustering among crop rotations under NT and forest area as compared to CT.

3. The effects of soil management and crop rotations systems on soil quality indicators are only evident upon an integrated analysis of the data by using mean test and principal component analysis.

\section{Acknowledgements}

The authors would like to thank CAPES by the financial support and Robert Boddey, Pedro Machado and
Phillip Chalk for the reading of manuscripts and relevant suggestions.

\section{References}

ALVAREZ, R. et al. Soil organic carbon, microbial biomass and $\mathrm{CO}_{2}-\mathrm{C}$ production from three tillage systems. Soil and Tillage Research, v. 33, n. 01, p. 17-28, 1995.

ANDERSON, T. H.; DOMSCH, K. H. Application of ecophysiological quotients $\left(\mathrm{qCO}_{2}\right.$ and $\left.\mathrm{qD}\right)$ on microbial biomasses from soils of different cropping histories. Soil Biology and Biochemistry, v. 22, n. 02, p. 251-255, 1990.

ARAÚJO, A. S. F.; SANTOS, V. B.; MONTEIRO, R. T. R. Responses of soil microbial biomass and activity for practices of organic and conventional farming systems in Piauí state, Brazil. European Journal of Soil Biology, v. 44, n. 02, p. 225-230, 2008.

BATJES, N. H. Mitigation of atmospheric $\mathrm{CO}_{2}$ concentrations by increased carbon sequestration in the soil. Biology and Fertility of Soils, v. 27, n. 03, p. 230-235, 1998

CARRERA, L. M. et al. Effects of cover crops, compost, and manure amendments on soil microbial community structure in tomato production systems. Applied Soil Ecology, v. 37, n. 03, p. 247-255, 2007.

DILLY, O. et al. Energetic eco-physiology of the soil microbiota in two landscapes of southern and northern Germany. Journal of Plant Nutrition and Soil Science, v. 164, n. 04, p. 407-413, 2001.

ELDER, J. W.; LAL, R. Tillage effects on gaseous emissions from an intensively farmed organic soil in North Central Ohio. Soil and Tillage Research, v. 98, n. 01, p. 45-55, 2008.

EUCLYDES, R. F. Sistema de análise estatística e genética SAEG. Viçosa, MG: Universidade Federal de Viçosa, 1982. p. 68.

FERREIRA, E. P. B. et al. Rhizosphere bacterial communities of potato cultivars evaluated through PCR-DGGE profiles. Pesquisa Agropecuária Brasileira, v. 43, n. 05, p. 605-612, 2008.

FERREIRA, E. P. B. et al. Assessing insecticide and fungicide effects on the culturable soil bacterial community by analyses of variance of their DGGE fingerprinting data. European Journal of Soil Biology, v. 45, n. 05/06, p. 466-472, 2009.

FIALHO, J. S. et al. Indicadores da qualidade do solo em áreas sob vegetação natural e cultivo de bananeiras na Chapada do Apodi-CE. Revista Ciência Agronômica, v. 37, n. 03, p. 250$257,2006$.

FRANCHINI, J. C. et al. Microbiological parameters as indicators of soil quality under various soil management and crop rotation systems in southern Brazil. Soil and Tillage Research, v. 92, n. 01/02, p. 18-29, 2007.

GUNDALE, M. J. et al. Restoration treatments in a Montana ponderosa pine forest: Effects on soil physical, chemical and biological properties. Forest, Ecology and Management, v. 213, n. 01/03, p. 25-38, 2005. 
HERMLE, S. et al. The effect of the tillage system on soil organic carbon content under moist, cold-temperate conditions. Soil and Tillage Research, v. 98, n. 01, p. 94-105, 2008.

JENKINSON, D. S.; LADD, J. N. Microbial biomass in soil: measurement and turnover. In: BOLLAG, J. M.; STOTSKY, G. Soil Biochemistry. New York: Marcel Dekker, 1981.p. 415-471.

JENKINSON, D. S.; POWLSON, D. S. The effects of biocidal treatment on metabolism in soil. V. Method for measuring soil biomass. Soil Biology and Biochemistry, v. 08, n, 03, p. 209-213, 1976.

JOLLIFE, I. T. Principal component analysis. 2th ed. New York: Springer Verlag, 2002. 487 p.

LEONARDOS, O. H.; THEODORO, S. H.; ASSAD, M. L. Remineralization for sustainable agriculture: A tropical perspective from a Brazilian viewpoint. Nutrient Cycling in Agroecosystems, v. 56, n. 01, p. 3-9, 2000.

MOSCATELLI, M. C. et al. Soil microbial indices as bioindicators of environmental changes in a poplar plantation. Ecological Indicators, v. 05, n. 03, p. 171-179, 2005.

MOSCATELLI, M. C. et al. Microbial indicators related to soil carbon in Mediterranean land use systems. Soil and Tillage Research, v. 97, n. 01, p. 51-59, 2007.

NOGUEIRA, M. A. et al. Promising indicators for assessment of agroecosystems alteration among natural, reforested and agricultural land use in southern Brazil. Agriculture, Ecosystems and Environment, v. 115, n. 01/04, p. 237-247, 2006.

OLDEMAN, L. R. The global extent of soil degradation. In: GREENLAND, D. J.; SZABOLCS, I. Soil Resilience and Sustainable Land Use. Wallingford: CAB International, 1999. p. 99-118.

RAUT, M. P. et al. Microbial dynamics and enzyme activities during rapid composting of municipal solid waste - A compost maturity analysis perspective. Bioresouce Technology, v. 99, n. 14, p. 6512-6519, 2008.

RESCK, D. V. S. Sistemas de manejo do solo e balanço de carbono no cerrado. In: LIMA, M. A. et al. Mudanças Climáticas Globais e a Agropecuária Brasileira. Jaguariúna: Embrapa Meio Ambiente, 2001. p. 231-255.
ROLDÁN, A. et al. Soil enzyme activities suggest advantages of conservation tillage practices in sorghum cultivation under subtropical conditions. Geoderma, v. 129, n. 03/04, p. 178-185, 2005.

SARMIENTO, L.; BOTTNER, P. Carbon and nitrogen dynamics in two soils with different fallow times in the high tropical Andes: indications for fertility restoration. Applied Soil Ecology, v. 19, n. 01, p. 79-89, 2002.

SENA, M. M. et al. Discrimination of management effects on soil parameters by using principal component analysis: a multivariate analysis case study. Soil and Tillage Research, v. 67, n. 02, p. 171-181, 2002.

SISTI, C. P. J. et al. Change in carbon and nitrogen stocks in soil under 13 years of conventional or zero tillage in southern Brazil. Soil and Tillage Research, v. 76, n. 01, p. 39-58, 2004.

TATE, K. R.; ROSS, D. J.; FELTHAM, C. W. A direct extraction method to estimate soil microbial $\mathrm{C}$ : effects of experimental variables and some different calibration procedures. Soil Biology and Biochemistry, v. 20, n. 03, p. 229-335, 1988.

ter BRAAK, C. J. F., SMILAUER, P. CANOCO reference manual and CanoDraw for Windows User's guide: Software for Canonical Community Ordination (version 4.5). Ithaca: Microcomputer Power, 2002. 352 p.

VANCE, E. D.; BROOKES, P. C.; JENKINSON, D. S. An extraction method for measuring soil microbial biomass C. Soil Biology and Biochemistry, v. 19, n. 06, p. 703-707, 1987.

VARGAS, L. K.; SCHOLLES, D. Biomassa microbiana e produção de $\mathrm{C}-\mathrm{CO}_{2}$ e $\mathrm{N}$ mineral de um podzólico vermelho escuro submetido a diferentes sistemas de manejo. Revista Brasileira de Ciência do Solo, v. 24, n. 01, p. 35-42, 2000.

WANG, Q.; WANG, S.; HUANG, Y. Comparisons of litterfall, litter decomposition and nutrient return in a monoculture Cunninghamia lanceolata and a mixed stand in southern China. Forest Ecology and Management, v. 255, n. 03/04, p. 12101218,2008

ZORNOZA, R. et al. Assessing the effects of air-drying and rewetting pre-treatment on soil microbial biomass, basal respiration, metabolic quotient and soluble carbon under Mediterranean conditions. European Journal of Soil Biology, v. 43, n. 02, p. 120-129, 2007. 